\title{
A reassessment of the tank battle between 4th Armoured Brigade and Panzerregiment 5 during Operation Crusader in North Africa on 19 November 1941
}

\author{
Andreas Biermann ${ }^{354}$ \\ SOAS University of London
}

\begin{abstract}
Operation Crusader took place in the wide context of an integrated, multi-service theatre-level offensive operation in the Western Desert and the Mediterranean from October 1941 through to January 1942. Seen through this lens, Operation Crusader was simply the Army and the Royal Air Force component of a multi-service theatre-level offensive conducted by Allied forces. The operation ended with an almost complete defeat of the Axis troops, the lifting of the seven-month siege of Tobruk and the retreat of the surviving Axis forces to a position on the border of the colonial provinces of Tripolitania and Cyrenaica, in central Libya.
\end{abstract}

Operation Crusader was the first army-level offensive undertaken by the Allied forces in World War II, lasting from 17 November 1941 to 15 January $1942 .{ }^{355}$ The aim of Operation Crusader was to trigger a large-scale tank battle with Axis tank forces outside the besieged desert port of Tobruk in Libya, to destroy the Axis armoured forces, and to pave the way to lift the siege of Tobruk, which had been conducted by the Axis forces since April 1941. Operation Crusader was the first step in a set of three operations expected to lead to the clearing of the North African coast from Axis forces and subsequently allow an invasion of Sicily in 1942. The battle was the largest tank offensive conducted by Allied forces in either World War I or World War II until the Second Battle of El Alamein in late October 1942. It was characterised by a number of tank battles between the Axis forces under the command of General der Panzertruppen Erwin Rommel and Allied infantry and armoured forces under Lieutenant-General Alan Cunningham and then Lieutenant-General Neil Ritchie, who fought under the overall direction of General Claude Auchinleck, the Commander-in-Chief Middle East. ${ }^{356} 357$

The conduct of the battle showed weaknesses in the doctrine of British armoured forces, but it ultimately ended in a victory for the Allied forces. This article analyses the first clash of British and German tanks during Operation Crusader and provides a new perspective on the performance of an experienced British cruiser tank regiment, which calls into question the overall assessment of how British armour performed during the battle. The re-assessment provided in this article is in particular related to the performance of both sides in the battle and the performance of both sides against their tactical objectives on the day, as well as the comparative losses in tanks. 
The article covers the first engagement of British $4^{\text {th }}$ Armoured Brigade with German armour during the opening stage of Operation Crusader between 17 and 20 November in which it managed to thwart a German counterattack. Utilising primary documents, such as war diaries, messages and reports, this article provides a new perspective on the established view of the battle that also affects our view of the performance of British armoured units at regimental level during this period of the Desert War. The article presents a reassessment of comparative tank combat performance in the early phase of Operation Crusader by analysing the first engagement between Allied and German armour with a view to correcting misconceptions that have until now clouded the historical record, such as the one expressed in General Auchinleck's despatch on the period, "But our tanks and anti-tank guns were no match for the German, although they were fought with great gallantry:". ${ }^{358}$ It also considers hitherto unused primary evidence to shed new light on the losses in tanks suffered by both sides during the battle, and considers how the opposing forces performed in the context of their operational objectives.

Keywords: World War II, Desert War, North Africa, Libya, $8^{\text {th }}$ Army, tank warfare, Tobruk, Afrika-Korps, Rommel, $7^{\text {th }}$ Armoured Division, Desert Rats, Lend-Lease Act, 1941.

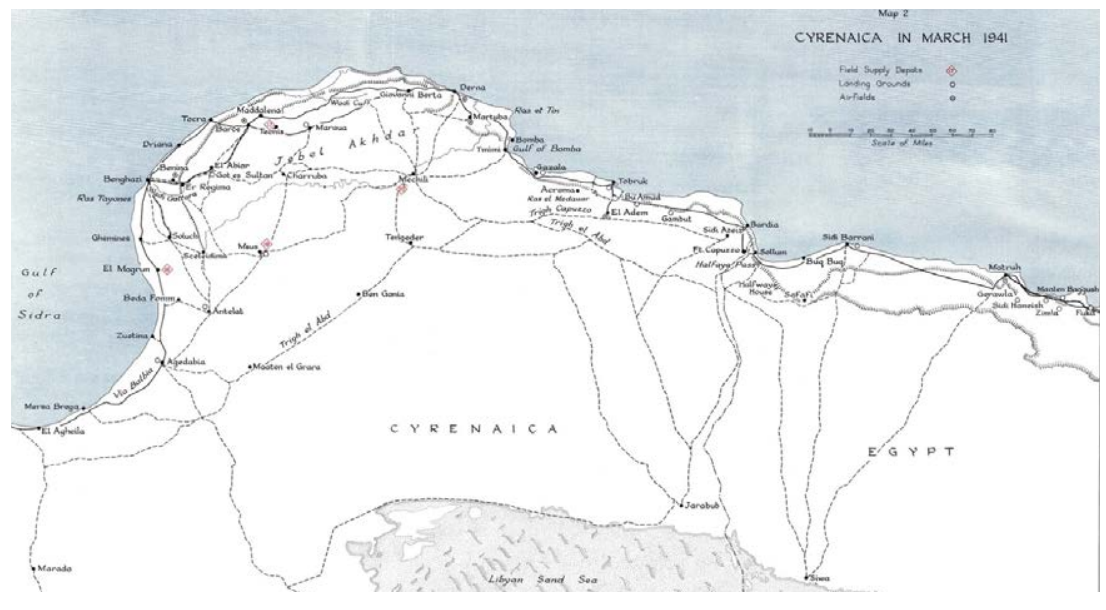

Map 1: Western Egypt, Eastern and Central Libya, March 1941..$^{359}$

\section{Introduction}

The War in the Desert, 1940-1943, remains an interesting subject of study for military history. The earlier controversies and debates on comparative military performance have been replaced by more nuanced scholarships concerning the occupation of North Africa, Nazi and Italian crimes and British imperialism. These old debates about the comparative performance of Allied and Axis armed forces in 
the ground battle nevertheless still simmer among scholars and the general public. This is particularly the case for the period 1941-1942, prior to General Bernard Law Montgomery's assuming command of the British $8^{\text {th }}$ Army and the replacement of Field Marshal Claude Auchinleck by Field Marshal Harold Alexander as commander of the Middle East theatre of war. This phase, lasting from December 1940 to July 1941, has been epitomised by Corelli Barnett as "[t]he cumulative and accelerating effects of twenty years of military decadence" suddenly being presented to the British generals. It was characterised by sweeping advances, covering hundreds of kilometres across the desert at rapid speeds, large-scale encirclement battles, and the siege of Tobruk, the longest siege endured by forces of the British Empire. ${ }^{360,361}$

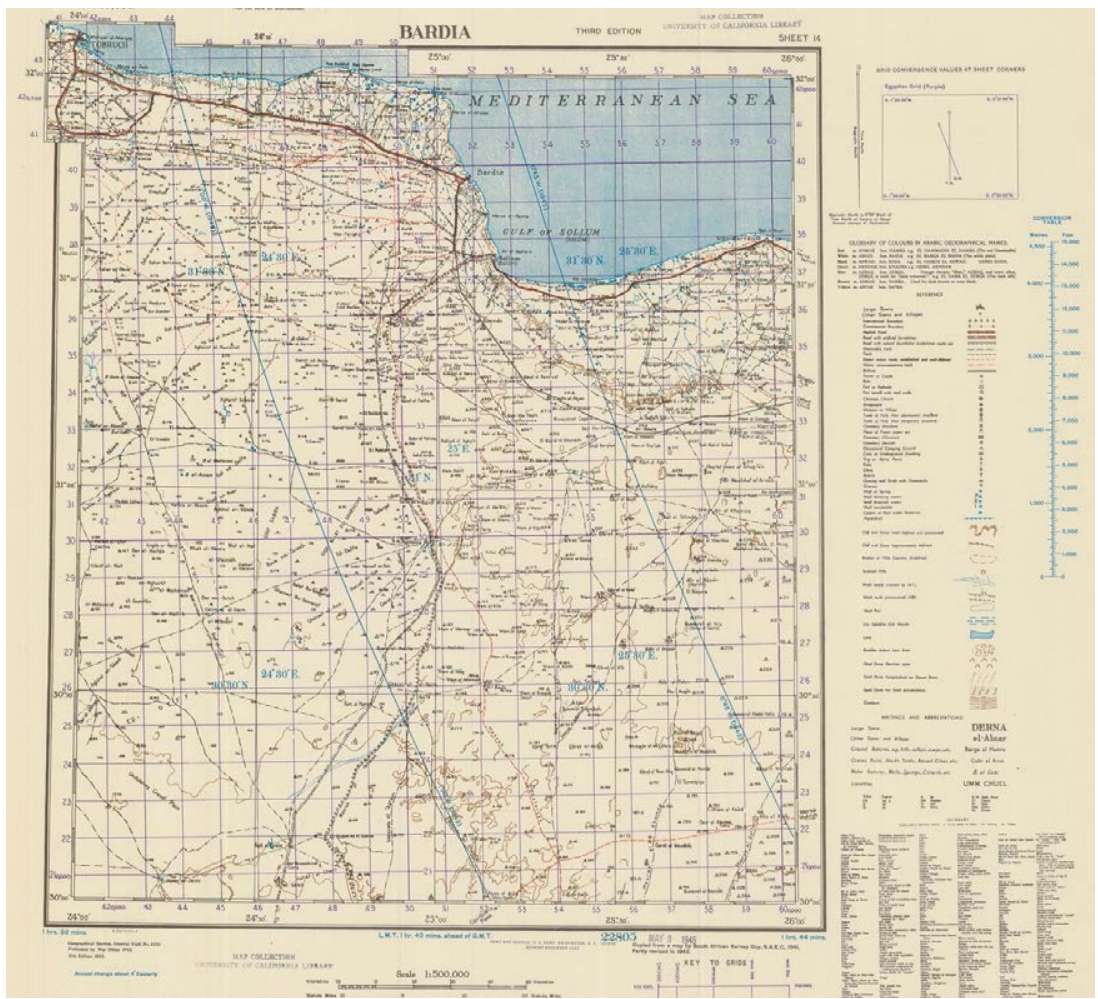

Map 2: The Operation Crusader battlefield. ${ }^{362}$

To break the siege of Tobruk through an offensive operation code-named Operation Crusader, a new army was created in September 1941, the $8^{\text {th }}$ Army under the command of Lt General Sir Alan Cunningham, who had been in charge of operations against the Italian forces in East Africa. The $8^{\text {th }}$ Army consisted of the former Western Desert Force, which was now named 13 Corps, the newly created 30 Armoured Corps and the Tobruk 
Fortress garrison, named TobFort. The $8^{\text {th }}$ Army was built around the largest tank force fielded by the British Empire until the time and it would ultimately see over 900 British and United States (US) tanks committed to battle in six brigades, the $2^{\text {nd }}, 4^{\text {th }}, 7^{\text {th }}$ and $22^{\text {nd }}$ Armoured Brigades and the $1^{\text {st }}$ and $32^{\text {nd }}$ Army Tank Brigades. ${ }^{363}$

The immediate objective of Operation Crusader was to destroy the Axis forces in North Africa, in particular the German armour, thereby relieving the siege of Tobruk, occupying the eastern Libyan province of Marmarica and the central Libyan province of Cyrenaica, and setting the stage for the elimination of the Axis forces on the North African mainland. The invasion of Tripolitania was to follow victory in Operation Crusader as a separate operation with an indicative code-name of Operation Acrobat. In 1942, this was to be followed by an invasion of Sicily, tentatively code-named Operation Gymnast, and the return of Allied forces to the mainland of Europe. Planning for both of the successive operations proceeded in the autumn 1941 in parallel with military operations in Libya. ${ }^{364,365}$

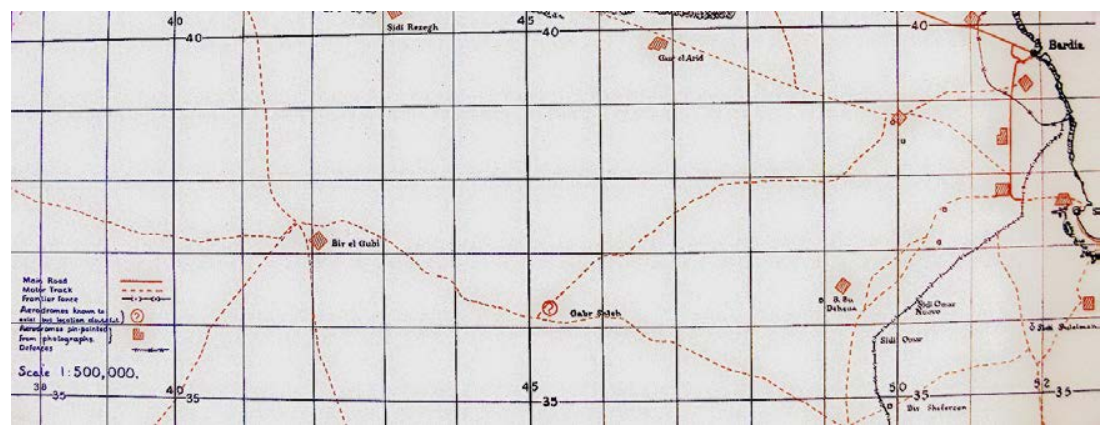

Map 3: British forces, theatre grid overlay, November $1941 .^{366}$

\section{Operational plans}

The operational plan for Crusader was for the $8^{\text {th }}$ Army's two Corps, 13 Corps on the right, and 30 Corps on the left, to bring to battle and destroy the armoured element of the Axis forces besieging Tobruk in a major tank battle south-east of Tobruk. One of the major concerns of the Allied commanders was the ratio of Allied to Axis, in particular German, tanks. For Operation Crusader, considering the overall tank strength of the $8^{\text {th }}$ Army, including TobFort and infantry tanks, this ratio amounted to 2.1 to 1. Nevertheless, for the cruiser tanks in 30 Corps, which were considered crucial to victory, this superiority only amounted to $1.5: 1$, as shown in Table 2 below.

Specifically, 30 Corps with the main armoured force of over 450 cruiser tanks in three brigades was to push on the left wing of the $8^{\text {th }}$ Army into the rear of the Axis position on the Libyan-Egyptian border. This was expected to trigger the tank battle in which the higher number of British tanks would enable the $8^{\text {th }}$ Army to prevail and destroy the Axis tank forces. The advance by 30 Corps on the left flank of the $8^{\text {th }}$ Army 
was covered by a shorter, northbound right hook of 13 Corps on the left flank. This was expected to envelop the rear of the Axis border position of Bardia-Sollum-HalfayaSidi Omar, approximately grid references 519398-525375-515370-498358 on Map 3 above. The operational objective of 13 Corps was the reduction of these positions along the Libyan-Egyptian border, thereby severing the supply routes from Bardia on the border to the forces besieging Tobruk to the west and protecting the rear of the 30 Corps advance. ${ }^{367}$

The $4^{\text {th }}$ Armoured Brigade was to be the hinge between the two corps in order to be able to support either, as needed. While assigned to 30 Corps logistically, the $4^{\text {th }}$ Armoured Brigade remained under operational control of the $8^{\text {th }}$ Army in the initial stage of the battle. Similarly, TobFort remained under command of the $8^{\text {th }}$ Army in the initial phase of the operation, with command to be transferred to 30 Corps once the situation warranted the issuing of the breakout order. In the event, the transfer happened on 20 November with the breakout order given for the following day.

\begin{tabular}{|c|c|c|c|c|}
\hline Type & 30 Armoured Corps & 13 Corps & Tobruk Fortress & Reserves \\
\hline \multirow[t]{2}{*}{ Armour } & $\begin{array}{l}7^{\text {th }} \text { Armoured Division } \\
\text { (two armoured brigades } \\
\text { and one support group) }\end{array}$ & $\begin{array}{l}1^{\text {st }} \text { Army Tank Brigade } \\
\text { (minus one squadron) }\end{array}$ & \multirow{2}{*}{$\begin{array}{l}32^{\text {nd }} \text { Army Tank } \\
\text { Brigade } \\
\text { (two regiments) }\end{array}$} & \multirow{2}{*}{$\begin{array}{l}\text { None in formations } \\
\text { but reserve tanks held } \\
\text { to replace losses. }\end{array}$} \\
\hline & \multicolumn{2}{|c|}{$4^{\text {th }}$ Armoured Brigade } & & \\
\hline \multirow{2}{*}{ Infantry } & $\begin{array}{l}1^{\text {st }} \text { South African } \\
\text { Infantry Division } \\
\text { (minus one brigade) }\end{array}$ & $2^{\text {nd }}$ New Zealand Division & $\begin{array}{l}70^{\text {th }} \text { Infantry } \\
\text { Division }\end{array}$ & $\begin{array}{l}2^{\text {nd }} \text { South African } \\
\text { Infantry Division } \\
\text { (plus one brigade) }\end{array}$ \\
\hline & $\begin{array}{l}22^{\text {nd }} \text { Guards Brigade } \\
\text { (two battalions) }\end{array}$ & $\begin{array}{l}4^{\text {th }} \text { Indian Infantry Division } \\
\text { (minus two brigades) }\end{array}$ & $\begin{array}{c}\text { Polish Carpathian } \\
\text { Brigade }\end{array}$ & $\begin{array}{l}5^{\text {th }} \text { and } 11^{\text {th }} \text { Indian } \\
\text { Infantry Brigade }\end{array}$ \\
\hline
\end{tabular}

Table 1: Composition of the $8^{\text {th }}$ Army at the start of Operation Crusader, major formations only, 17 November $1941 .^{368}$

\begin{tabular}{|c|c|c|c|c|c|c|c|c|}
\hline Type & \multicolumn{2}{|r|}{$8^{\text {th }}$ Army } & \multicolumn{2}{|c|}{ Panzergruppe $^{369}$} & \multicolumn{2}{|c|}{$\boldsymbol{X X}$ C.A.M. ${ }^{370}$} & Total & $\begin{array}{c}\text { Ratio } 8^{\text {th }} \text { Army } \\
\text { to Axis }\end{array}$ \\
\hline \multirow{2}{*}{ Medium $^{1}$} & $315^{2}$ & Cruiser British & 144 & Panzer III & \multirow{2}{*}{136} & \multirow{2}{*}{$\mathrm{M} 13 / 40$} & \multirow{2}{*}{799} & \multirow{2}{*}{$1.5: 1^{3}$} \\
\hline & 166 & M3 Stuart & 38 & Panzer IV & & & & \\
\hline \multirow{2}{*}{ Infantry ${ }^{4}$} & $152^{5}$ & Matilda II & \multirow{2}{*}{5} & \multirow{2}{*}{ Matilda II } & \multirow{2}{*}{\multicolumn{2}{|c|}{$\mathrm{n} / \mathrm{a}$}} & \multirow{2}{*}{209} & \multirow{2}{*}{$41: 1$} \\
\hline & 52 & Valentine & & & & & & \\
\hline \multirow{2}{*}{ Total } & \multirow{2}{*}{\multicolumn{2}{|c|}{$685^{6}$}} & & 187 & & 36 & 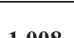 & \multirow{2}{*}{ 2.1:1 } \\
\hline & & & \multicolumn{4}{|c|}{323} & 1008 & \\
\hline
\end{tabular}

Table 2: Tank strength, medium and infantry tanks, $8^{\text {th }}$ Army, Panzergruppe Afrika and XX Corpo Armata di Manovra, 17 November 1941. ${ }^{371}$

${ }^{1}$ TNA WO169/952 Tank statistics Eighth Army 11 November 1941; WO201/520 $7^{\text {th }}$ Armoured

Division Account on Operations in Libya, 18 November to 27 December 1941, p. 8

${ }^{2}$ Includes 28 cruiser tanks in TobFort 
${ }^{3}$ The superiority of 30 Corps was only 1.4:1.

${ }^{4}$ TNA WO169/1418 8 RTR November 1941; TNA WO169/1413 war diary 4 RTR November 1941, Appendix I; TNA WO169/1421 war diary 42 RTR entry 14 November 1941.

${ }^{5}$ Includes 67 Matilda II infantry tanks in TobFort.

${ }^{6}$ Excluding reserves and excluding C Squadron 42 RTR, which only joined battle on 25 November.

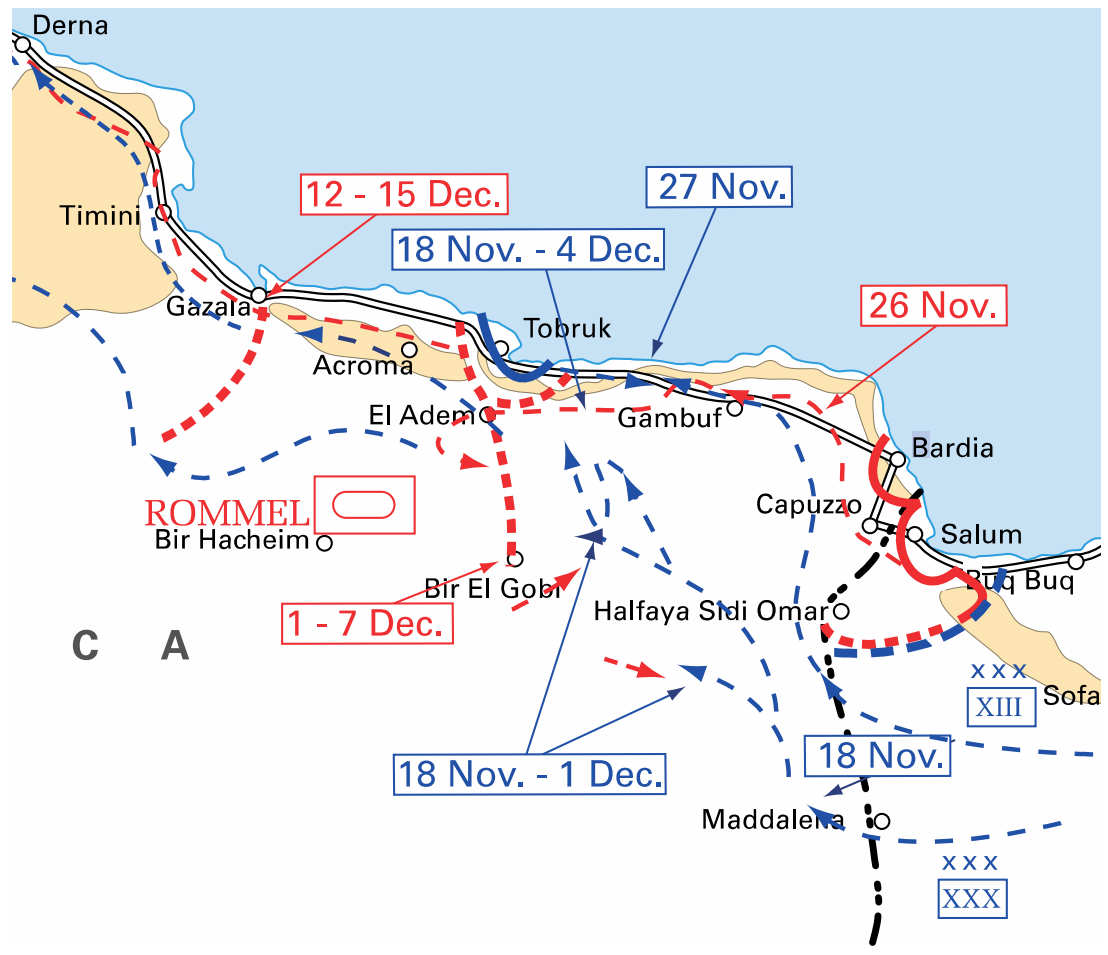

Map 4: Operation Crusader movements, 18 Nov. to 17 Dec. $1941 .{ }^{372}$

Concurrent with the Allied planning for Operation Crusader, the Axis forces in North Africa were planning their assault on the fortress of Tobruk, an operation scheduled for 23 November 1941, following considerable delays occasioned by a struggle to build up sufficient forces and supplies. Throughout the summer and early autumn of 1941, the effective blockading efforts by the Royal Air Force and Royal Navy, interdicting Axis supplies and troops moving into North Africa, as well as supply difficulties caused by the nature and distances of the theatre, negatively affected the build-up of Axis forces in preparation for the assault. ${ }^{373}$

Preparing for the assault on Tobruk while simultaneously ensuring the defence of the border and rear of the assault force was complicated further by the structure of the Axis forces, who fought a coalition war with convoluted command arrangements. As a consequence, the Axis operational command structure was more complex than that of 
the $8^{\text {th }}$ Army, reflecting the coalition nature of the forces. All German and most Italian forces were under the command of Panzergruppe Afrika, a command structure between the level of Army and Corps under General der Panzertruppen Erwin Rommel.

Rommel nominally reported to the Comando Superiore Forze Armate Africa Settentrionale under Field Marshal Ettore Bastico but also maintained a direct line of communication to the German headquarters (HQ) in Berlin, through the German Army attaché in Rome, General von Rintelen. The remaining Italian forces in the operational zone in eastern Libya's Marmarica province were concentrated in the Corpo Armata di Manovra under General Gastone Gambara, who simultaneously was General Bastico's Chief of Staff, and reported directly to this command. ${ }^{374},,^{375}, 376,377,378$

\begin{tabular}{|c|c|c|c|}
\hline \multirow{2}{*}{ Nationality } & \multicolumn{3}{|c|}{ Comando Superiore Forze Armate Africa Settentrionale } \\
\hline & \multicolumn{2}{|c|}{ Panzergruppe Afrika } & $\begin{array}{l}\text { XX Corpo Armata di } \\
\text { Manovra (CAM) }\end{array}$ \\
\hline \multirow{6}{*}{ German } & \multirow{4}{*}{ Deutsches Afrika-Korps } & $15^{\text {th }}$ Panzerdivision & \\
\hline & & $21^{\text {st }}$ Panzerdivision & \\
\hline & & Division z.b.V. Afrika ${ }^{379}$ & \\
\hline & & Reconnaissance Group Wechmar & \\
\hline & \multicolumn{2}{|l|}{ Artillery Command 104} & \\
\hline & Sektor West ${ }^{1}$ & Bardia Garrison & \\
\hline \multirow[t]{6}{*}{ Italian } & $\begin{array}{c}\text { Sektor Ost - Halfaya } \\
\text { Pass }\end{array}$ & Savona infantry division & $\begin{array}{c}\text { Ariete armoured } \\
\text { division }\end{array}$ \\
\hline & \multirow{5}{*}{$\begin{array}{l}\text { XXI Corpo Armata } \\
\text { (Tobruk siege lines) }\end{array}$} & Brescia infantry division & $\begin{array}{l}\text { Trieste motorised } \\
\text { infantry division }\end{array}$ \\
\hline & & Trento motorised infantry division & \multirow{4}{*}{$\begin{array}{c}\text { Recam - } \\
\text { reconnaissance } \\
\text { detachment of the } \\
\text { Mobile Corps }\end{array}$} \\
\hline & & Pavia infantry division & \\
\hline & & Bologna infantry division & \\
\hline & & Corps Artillery & \\
\hline
\end{tabular}

Table 3: Composition of Axis forces in Marmarica at the start of Operation Crusader, 17 November 1941.380

${ }^{1}$ Sektor West and Sektor Ost (west and east) both consisted of mixed German and Italian garrison and static combat forces.

The German plan to guard the rear of the forces assaulting the fortress of Tobruk included, first, the creation of a reinforced armoured reconnaissance group to conduct patrols south of Gasr el Arid and east of Sidi Omar, to provide early warning in case of an offensive from the south. Second, it foresaw the placing of $21^{\text {st }}$ Panzerdivision on the Trigh Capuzzo at Gasr el Abid (map location 469399 on Map 3 above). 
The reinforced armoured reconnaissance group was named Aufklärungsgruppe Wechmar after its commander, referred to as Gruppe Wechmar. It consisted of the two German armoured reconnaissance battalions, Aufklärungsabteilung (AA) 3 of $21^{\text {st }}$ Panzerdivision and AA 33 of $15^{\text {th }}$ Panzer, reinforced by the HQ and third company of Anti-Tank Battalion 39 of $21^{\text {st }}$ Panzer. Around 15 November, Gruppe Wechmar was placed west of Sidi Omar with AA 3 and the mass of the anti-tank (AT) guns immediately west and AA 33 with one $5 \mathrm{~cm}$ AT-gun platoon further west. ${ }^{381},{ }^{382}, 383$

On 15 November, the German Afrika-Korps' $21^{\text {st }}$ Panzerdivision was ordered to take up its covering position, from where it could easily move south to counter a British spoiling attack. During the move, the division ran low on fuel and required replenishment, but this did not happen in time for battle on 19 November, and the infantry elements of the division remained immobilised. ${ }^{384}$

\section{The opposing forces}

The orders of battle of both armies were finely balanced in terms of numbers of men, while the advantage in tank numbers lay clearly on the Allied side, and in artillery, in both numbers of guns and calibre on the Axis side.

The Allied tank forces used a wide variety of types, including both British-built cruiser and infantry tanks, and US-built cruiser tanks. The $4^{\text {th }}$ Armoured Brigade was the only tank brigade in $8^{\text {th }}$ Army to be equipped with US-built M3 tanks, which it had received during the summer of 1941 . Its three tank regiments, $3^{\text {rd }}$ and $5^{\text {th }}$ Royal Tank Regiment (RTR) and $8^{\text {th }}$ King's Royal Irish Hussars ( $8^{\text {th }}$ Hussars) had extensive combat experience, having been in action since 1940. The Brigade's Commanding Officer, Brigadier Alexander Gatehouse, MC, had led $4^{\text {th }}$ Armoured Brigade during Operation Battleaxe in June 1941, skilfully commanding the defence at Fort Capuzzo that allowed British infantry forces to escape east. Bob Crisp, then a captain and troop commander and second-in-command of C Squadron 3 RTR, described Gatehouse as "a tank officer as distinct from a cavalry officer, and who was probably the best handler of armor in the desert at the time". 385

The Brigade was equipped with 166 M3 Stuart (M3) tanks, and a further 22 M3 tanks held forward in first-line reserve. The three tank regiments were each equipped with 52 tanks in three squadrons and an HQ section, accounting for $156 \mathrm{M} 3$ tanks in total. A further $10 \mathrm{M} 3$ tanks were held at Brigade HQ, to mount the HQ and an unknown number of artillery observer parties. ${ }^{386}$ While the $8^{\text {th }}$ Hussars was an old cavalry regiment, they had been mechanised in 1935, and by 1941 had served in the Middle East for a considerable period of time, seeing combat in Operation Compass against Italian forces.

The main weapon of the regiment was the new M3 Stuart tank, received under lendlease from US factories. This was a reliable vehicle, demonstrated by the fact that only one tank in the Brigade fell out during the approach march. ${ }^{387}$ The Stuart had a relatively high fuel consumption, limiting range in the desert to about 60 miles (approximately 
96.5 kilometres). This was to affect the conduct of the battle on 19 November, with dispersed tank units of $4^{\text {th }}$ Armoured Brigade having to refuel prior to being able to join combat, or indeed remaining stranded in the middle of the desert, unable to intervene.

The Brigade had attached to it considerable all-arms support. This included the $2^{\text {nd }}$ Royal Horse Artillery (RHA), a 25-pdr (25-pounder) regiment with two eight-gun batteries, and $102^{\text {nd }}$ (Northumberland Hussars) AT Regiment Royal Artillery (RA) minus one battery, equipped with 24 2-pdr portée AT guns. ${ }^{388}$ These were complemented by $2^{\text {nd }}$ Scots Guards, who provided motorised infantry and $112^{\text {th }}$ Light Anti-Aircraft (LAA) Battery, 13 ${ }^{\text {th }}$ LAA Regiment for air defence with $1240 \mathrm{~mm}$ Bofors anti-aircraft guns. Reconnaissance was provided by A and B squadrons of the King's Dragoon Guards (KDG) who were equipped with South African-built Marmon Herrington Mk III armoured cars.

On the Axis side, the protection of the rear of the assault on Tobruk was allocated to $21^{\text {st }}$ Panzerdivision, an under-strength division that had only been formed in North Africa in August 1941 from $5^{\text {th }}$ Light Division and other independent army troops that had been sent to North Africa during the spring and summer of 1941. The division's main striking force was its armoured regiment, Panzerregiment 5, under LieutenantColonel Stephan. ${ }^{389}$ The regiment had extensive desert combat experience.

Panzerregiment 5 was equipped with three different types of combat tanks: 35 light tanks Panzer II, 68 medium tanks Panzer III, and 17 of the (by 1941 standards) heavy tanks Panzer IV. While the Panzer III had a superior gun, deferring a range advantage on it, neither the Panzer II with its automatic $20 \mathrm{~mm}$ gun, nor the Panzer IV with its $75 \mathrm{~mm}$ howitzer could claim to outgun the Stuart tank. In terms of armour, all three types of tanks were vulnerable to the $37 \mathrm{~mm}$ gun of the Stuart and indeed the 2-pdr of British tanks over standard combat ranges, as they had not been up-armoured at that stage of the war. Furthermore, it was not fully appreciated by Allied commanders at the time that the Panzer III carried a 50mm gun, with at least some commanders considering that it continued to carry a $37 \mathrm{~mm}$ gun as had been the case with earlier models in France. ${ }^{390}$ Contrary to the general belief that emerged after Operation Crusader, the Panzer IIIG was more lightly armoured than the Allied tanks it opposed.

Despite the claim in the $5^{\text {th }}$ RTR war diary that " $[\mathrm{t}]$ he enemy had superiority in numbers, his tanks were more heavily armoured, they had larger calibre guns with nearly twice the effective range of ours, and their telescopes were superior" the tanks were actually relatively evenly matched. ${ }^{391}$ While the Panzer III was considered a more capable tank overall - and, in particular, the Stuart was considered to be comparatively lightly armoured - the two tanks had comparable combat capabilities. The Stuart's frontal armour was in fact superior to that of the German Panzer IIIG, which made up the bulk of the tank force of Panzerregiment 5 during Operation Crusader. Furthermore, the M3 Stuart's 37mm M5 gun performed similarly to the German 50mm KWK 38 tank gun equipping the Panzer III models in the desert in 1941. This meant that, on the battlefield, both sides were relatively evenly matched. 


\begin{tabular}{|c|c|c|c|c|c|}
\hline Armour & Panzer IIIG & M3 Stuart & $\begin{array}{c}\text { Gun } \\
\text { performance }\end{array}$ & $\begin{array}{c}\text { Panzer IIIG } \\
50 \mathrm{~L} 42\end{array}$ & $\begin{array}{l}\text { M3 Stuart } \\
\text { M5 37 mm }\end{array}$ \\
\hline Location & \multicolumn{2}{|c|}{ Armour in $\mathrm{mm}$} & $\begin{array}{l}\text { Distance } \\
\text { yards } / m^{I}\end{array}$ & \multicolumn{2}{|c|}{ Penetration in $\mathrm{mm}^{2}$} \\
\hline Lower front hull & 25 & 44 & 500 & 47 & 46 \\
\hline Upper front hull & 30 & 38 & 1000 & 37 & 40 \\
\hline Gun mantlet & 30 & 38 & 1500 & 28 & 38 \\
\hline Turret front & 30 & 38 & 2000 & $\mathrm{n} / \mathrm{a}$ & 33 \\
\hline Turret sides & 30 & 25 & & & \\
\hline Hull sides & 30 & 25 & & & \\
\hline
\end{tabular}

Table 4: Comparative armour strength in mm of the Panzer IIIG and the M3 Stuart. ${ }^{392}$

${ }^{1}$ US tank gun performance distance was measured over distances in yards, while German tank gun performance was measured over distances in meters. The penetration figures refer to the respective distances as reported by the two armies. Thus, the 50L 42 penetrated $47 \mathrm{~mm}$ at 500 meters and the M5 $37 \mathrm{~mm}$ gun penetrated $46 \mathrm{~mm}$ at 500 yards.

${ }^{2}$ Panzer III penetration against homogenous rolled steel at vertical angle, 50\% success, distance in metres; M3 Stuart against face-hardened steel at 30 degrees off the vertical angle, distance in yards.

\section{Approach to contact}

On the morning of 19 November, $21^{\text {st }}$ Panzerdivision was at Gasr el Arid, facing south, with a combined armoured reconnaissance formation named Group Wechmar in front of it. In response to the growing Allied pressure on Group Wechmar from 18 November onwards, the division formed a combat group around its armoured regiment, Battle Group Stephan, to attack and eliminate the Allied tank forces to the south. ${ }^{393}$

Battle Group Stephan was formed around mid-day on 19 November 1941 by $21^{\text {st }}$ Panzerdivision to back up Group Wechmar by flanking the enemy force west of Sidi Omar. ${ }^{394}$ The size and composition of Group Stephan were restricted by petrol shortages and it therefore consisted of Panzerregiment 5, II/AR155, a light field howitzer artillery battalion and 3/Flak 18, a mixed anti-aircraft gun battery. ${ }^{395}$ The units of Group Stephan were experienced, having fought Allied forces since April 1941 and its commander, Colonel Stephan, had led the regiment since July 1941. 


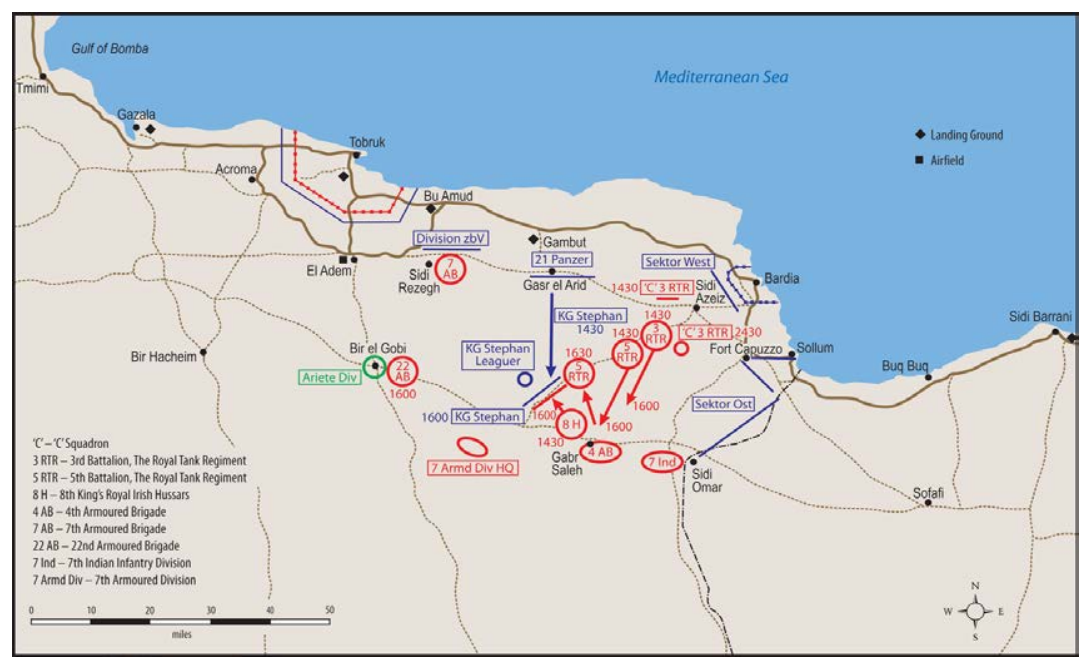

Map 5: Positions of $7^{\text {th }}$ Armoured Division and 21 Panzerdivision, 18 November, and direction of moves of $4^{\text {th }}$ Armoured Brigade and Group Stephan, 19 November $1941,14: 30$ to $24: 00 .^{396}$

Allied movements commenced on 17 November 1941 when the first of $8^{\text {th }}$ Army's forces crossed the 'wire' marking the border between Egypt and Libya. The objective for $4^{\text {th }}$ Armoured Brigade was Gasr Taieb el Essem (location 470357 on Map 3 above), on the Trigh el Abd just short of the corps pivot point Gabr Saleh (location 452362 on Map 3 above). The brigade moved across the wire during the morning of 18 November and arrived at its destination with no noteworthy events. For the next day, 19 November, $7^{\text {th }}$ and $22^{\text {nd }}$ Armoured Brigades were ordered to continue the advance west and north, $4^{\text {th }}$ Armoured Brigade was ordered to remain at Gabr Saleh, pushing reconnaissance to the 450 grid line to cover the rear of $7^{\text {th }}$ Indian Brigade, which began their operations by investing the desert locations of Libyan Omar and Sidi Omar that day. ${ }^{397}$

The first indication of the Allied advance arrived at German commands on the morning of 18 November, when Group Wechmar reported being engaged by superior forces, the reconnaissance screen of $7^{\text {th }}$ Armoured Division. Messages became more urgent during the day and 21 st Panzerdivision requested permission from Generalleutnant Ludwig Crüwell, the commander of the Africa Corps, to back up Group Wechmar by moving its Panzerregiment south to Gabr Saleh. ${ }^{398},{ }^{399}$ This request was denied under instruction from Rommel who considered the advance to be a raid. This view is reflected in the Panzergruppe intelligence summary for 18 November. ${ }^{400}$

Nevertheless, a single light tank company, 1st Company Panzerregiment 5, was sent to back up Group Wechmar on this day. Furthermore, at 22:00, 15th Panzerdivision was ordered to prepare for movement and the preparatory code-word 'Ebbtide' was issued to it. 
On the Allied side, given the continued uncertainty about the actions by the Axis command in reaction to the Allied advance, Brigadier Gatehouse was ordered to remain at Taieb el Essem. Consequently, 4th Armoured Brigade issued orders at 16:05 to its armoured regiments to take a position shielding the Trigh el Abd towards the north and east and blocking it at Point (Pt.) 190 at the south-eastern end of the brigade line. The line ran from the west at Pt. 186 (location 460363 on Map 2) to Bir el Barrani and then turning south to Pt. 190 (location 472357 on Map 2), with Bir el Barrani as its pivot point. Aligned north-south and facing east from Pt. 190 to Bir el Barrani inclusive were 5th RTR and aligned west-east facing north from Bir el Barrani exclusive to Pt. 186, was 8th Hussars. The line took advantage of a ridge line, which would have provided good observation to the north, and faced a slightly rising plateau to the east. The Brigade reserve was 3rd RTR at Pt. 185 (464356 on Map 2), just a few kilometres to the south and equidistant from the other two regiments, while the brigade HQ and support were in the centre of the position. At the end of the day, Brigadier Gatehouse had created a strong position that enabled rapid deployment of the fully concentrated brigade in any direction. ${ }^{401}$

\section{First clash - 19 November 1941}

For operations on 19 November, Panzergruppe ordered its attached short-range reconnaissance unit, $2(\mathrm{H}) / 14$ to undertake a morning aerial reconnaissance. The area to be covered was a rectangle of Bir el Gobi-El Mfaues-Maddalena-Gasr el Arid (418378-446278-505299-4740 on Map 2) to ascertain the strength of the Allied forces in this area and whether they were accompanied by tanks. The reconnaissance was, however, cut short due to radio failure, and the results were reported at 09:00, noting the presence of hundreds of trucks and 40 armoured cars. ${ }^{402}$ A late morning reconnaissance flight again reported only trucks and guns. Finally, a reconnaissance flown on the line Bir el Gubi-Sidi Omar reported large numbers of tanks at 12:15. ${ }^{403}$

On the ground, the eastern element of Group Wechmar spent the morning of 19 November in a running fight with KDG armoured cars, and throughout the day continued to engage these, as well as $3^{\text {rd }}$ and $5^{\text {th }}$ RTR. They rapidly pushed Group Wechmar northwest. At 10:00, another company of Panzerregiment 5, $2^{\text {nd }}$ Company, was dispatched east from Gasr el Arid to try and destroy enemy armoured cars stuck in a swamp. At 11:30, Panzerregiment 5 was verbally ordered by $21^{\text {st }}$ Panzerdivision's commander, Generalmajor Johann von Ravenstein, to assemble as Group Stephan with assigned units at Gasr el Arid. Group Stephan was to move south to Gabr Saleh, then turn east towards Sidi Omar to flank and destroy the 200 enemy tanks that Group Wechmar had reported there. At this time, the two detached tank companies were recalled, although the 1st Company would not re-join until the march south was underway. ${ }^{404}$ At 11:45, the order to Group Stephan was confirmed and the code words 'Flood' and 'High Water' were issued by the Afrika-Korps command to all units of 15 Panzerdivision, triggering its departure into the forward areas. Communication was disrupted due to the flooding during the night of 17-18 November, which had destroyed many wire communications in the divisional area. ${ }^{405}$ 
At 08:00, Crüwell, commander of the Afrika-Korps, visited $21^{\text {st }}$ Panzer's command post and was informed of von Ravenstein's intent and that, due to petrol and ammunition shortages, the mass of the division had to form a hedgehog defence. Following further discussion with Rommel, who visited $21^{\text {st }}$ Panzerdivision's command post at 13:30, Panzergruppe issued confirming orders for Group Stephan at 14:40, which had already commenced its advance south at 13:20. It took slightly over 2,5 hours to assemble, prepare to move and cover the distance of about $30 \mathrm{~km}$.

On 19 November - despite his orders to remain at Taieb el Essem - Gatehouse commenced a set of piecemeal operations at regimental level, and $4^{\text {th }}$ Armoured Brigade therefore could not fight a brigade battle. He ordered $3^{\text {rd }}$ RTR and $5^{\text {th }}$ RTR, supported by $\mathrm{H} / \mathrm{I}$ battery of $2^{\text {nd }}$ RHA, to work with the KDG patrols in order to strengthen them and continue the clearance of the sector just west of the border. By early afternoon, the tank force of the brigade was thus disposed on a 40-kilometre line from Taieb el Essem north-east to the Trigh Capuzzo. Only $8^{\text {th }}$ Hussars and B Squadron $5^{\text {th }}$ RTR remained near Taieb el Essem, together with some support units and brigade HQ and reserve. ${ }^{406}$

This was the situation when at $15: 30,7^{\text {th }}$ Armoured Brigade reported to $7^{\text {th }}$ Armoured Division that 100 tanks were moving south-east, and that $4^{\text {th }}$ Armoured Brigade had been alerted and had acknowledged the receipt of the message. ${ }^{407}$ The $4^{\text {th }}$ Armoured Brigade war diary notes the disposition of the brigade and the intent to concentrate its forces in reaction to the attack by Group Stephan, in particular, that $5^{\text {th }}$ RTR was recalled. At this point, only $8^{\text {th }}$ Hussars and the brigade reserve, B Squadron $5^{\text {th }}$ RTR, were available to stop the German advance. Almost immediately, $8^{\text {th }}$ Hussars was moved north-east into a blocking position to face the German attack on the track Gabr Saleh-Sidi Azeiz. A troop of $2^{\text {nd }}$ RHA's L/N Battery and a battery of anti-tank guns were also ready to support. By 16:00, $8^{\text {th }}$ Hussars had advanced to the assigned line and was ready to receive the German tanks. No warning of the attack by Group Stephan was received by $8^{\text {th }}$ Hussars other than an alert by the regiment's own reconnaissance troop. ${ }^{408}$

\begin{tabular}{|c|c|c|}
\hline Force element & Group Stephan & $4^{\text {th }}$ Armoured Brigade \\
\hline Tanks & $\begin{array}{c}85 \text { Medium (68 Panzer III and } \\
17 \text { IV) } \\
35 \text { Light (Panzer II) } \\
4 \text { Command }\end{array}$ & $\begin{array}{c}52 \mathrm{M} 3\left(16: 00-8^{\text {th }} \text { Hussars) }\right. \\
104 \mathrm{M} 3 \text { (from 16:30 }-8^{\text {th }} \text { Hussars and } 5^{\text {th }} \text { RTR) }\end{array}$ \\
\hline Artillery & $12105 \mathrm{~mm}$ howitzer $1 \mathrm{FH} 18$ & $\begin{array}{l}\text { 4 25-pdr guns ( } 16: 00-\mathrm{H} \text { Troop) } \\
8 \text { 25-pdr guns (from 16:30 - H Troop and I } \\
\text { Troop, the latter supporting } 5^{\text {th }} \text { RTR) }\end{array}$ \\
\hline Anti-tank/anti-air & $\begin{array}{l}488 \mathrm{~mm} \text { guns } \\
220 \mathrm{~mm} \text { guns }\end{array}$ & 12 2-pdr portée guns \\
\hline
\end{tabular}

Table 5: Estimated strength of opposing forces at Gabr Saleh, 19 November 1941, 16:00-18:00.409 


\section{The battle}

At 16:02, $4^{\text {th }}$ Armoured Brigade reported to $7^{\text {th }}$ Armoured Division that it was heavily engaged, while on the German side, Panzerregiment 5 noted that, at 16:00, Group Stephan met 130 enemy tanks; a number which later increased to $180 .{ }^{410},{ }^{411}$

Based on the war diary of $8^{\text {th }}$ Hussars, following an air attack that struck both Brigade HQ and $8^{\text {th }}$ Hussars, Group Stephan advanced to within 1500 yards from $8^{\text {th }}$ Hussars before opening into battle formation. Group Stephan then closed to 700 yards, which was sufficient for the $37 \mathrm{~mm}$ guns of the M3 tanks to be able to penetrate German armour. German shooting was reported as accurate by $8^{\text {th }}$ Hussars, with tanks being hit while the M3 tanks were still outranged.

There is no evidence in the primary record of the battle being fought at closer range than 700 yards. An entry in the $8^{\text {th }}$ Hussars war diary of 20 November noted, "the enemy $[\ldots]$, in many cases, came in closer than the previous day", indicating that there was a range gap between the two opposing forces, rather than the point-blank melee indicated by Alan Moorehead. ${ }^{412}$ Considered in tactical terms, the engagement seems to have been a short-range firefight, rather than a manoeuvre battle. No attempt to flank $8^{\text {th }}$ Hussars was made by Group Stephan until late in the battle. Colonel Stephan had by then however missed his chance and this flanking attempt was held off by $5^{\text {th }}$ RTR who had appeared on the right flank of $8^{\text {th }}$ Hussars.

German reports, confirming eye-witness reports, note that $8^{\text {th }}$ Hussars fought a mobile battle, using the speed of the M3. Over time, the superiority in enemy numbers increased until about 180 tanks were presumed to be in action on the Allied side, a considerable over-estimate. ${ }^{413}$ The German reports also note that enemy pressure was highest on the left (eastern) flank of Group Stephan, in line with a supposition that, rather than frontally, Group Stephan had hit the line of $8^{\text {th }}$ Hussars at an angle. It is also on this flank that $5^{\text {th }}$ RTR appeared late in the battle.

At $16: 24,4^{\text {th }}$ Armoured Brigade reported to $7^{\text {th }}$ Armoured Division that the enemy advance had been halted at Pt.189 (464363 on Map 2), and at 17:00 and 17:28 that the battle was continuing. ${ }^{414}$ The brigade reserve was not committed until all of $5^{\text {th }}$ RTR had arrived at Taieb el Essem, around 16:30, when its war diary reported the regiment to be in action. ${ }^{415}$ As $5^{\text {th }}$ RTR did not report tank casualties other than two mechanical failures, it does not appear that $5^{\text {th }}$ RTR closed the range with the enemy, rather, it is reported to have fought at a distance. ${ }^{416}$ At $18: 58,4^{\text {th }}$ Armoured Brigade reports that the battle ended at last light with a German withdrawal. For unknown reasons, official histories and some war diaries claim that $8^{\text {th }}$ Hussars left the battlefield to Group Stephan, even though both sides in fact withdrew from the site of the battle, leaving disabled tanks in no-man's land. Both sides undertook recovery actions during the night. One of the disabled German tanks could not be recovered due to enemy presence, further showing that the German overnight leaguer was not on the site of the battle. ${ }^{417}$

During the engagement, it is likely that heavy dust reduced visibility, and this made effective use of the artillery difficult for the Germans. For example, the $12105 \mathrm{~mm}$ 
howitzers of Group Stephan only fired 54 rounds in total, while the four $88 \mathrm{~mm}$ guns fired only 166 rounds. The $88 \mathrm{~mm}$ guns also claimed only two of the total $24 \mathrm{M} 3$ Stuarts reported as destroyed by Group Stephan. The medium tanks, on the other hand, fired 2382 rounds and the light tanks, 410 rounds. By contrast, $2^{\text {nd }}$ RHA reported firing 300 rounds from its eight 25-pdrs during the course of the engagement. Dust would also have made control difficult, and the records indicate that Gatehouse did not exert close control, maybe also due to repeatedly coming under fire by the German artillery and having to displace three times. ${ }^{418}$

\section{Assessment}

The tactical situation at the end of the engagement was that both sides claimed victory. The $4^{\text {th }}$ Armoured Brigade reported that it had given the Germans a "good knock", estimating 19 to 26 enemy tanks destroyed as well as nine troop carriers, some of which by artillery and AT guns. In addition, $8^{\text {th }}$ Hussars estimated they had destroyed 20 tanks, noting, "this was a good performance". ${ }^{419}$ In terms of their own losses, 20 tanks were reported lost, but no breakdown by type of casualty was provided. ${ }^{420}$

On the German side, Panzerregiment 5's evening report overestimated British tank numbers in the engagement by conflating $8^{\text {th }}$ Hussars and $5^{\text {th }}$ RTR as if they had faced them throughout, and claimed that the attacking British tanks were driven back from their position. This was repeated by Panzergruppe to Berlin, ignoring the objectives that were given to Group Stephan, instead focusing on terrain occupied and enemy tanks destroyed. ${ }^{421}$

In operational terms, it is worth considering that the view by $8^{\text {th }}$ Hussars was justified. With only minimal support, the regiment had held off a superior force, held the line and prevented the German tanks from moving east. Nevertheless, while Brigadier Gatehouse had prevented the Germans from achieving their operational objectives of destroying his brigade and of advancing to Sidi Omar, he had also failed to deal the German tank force a major blow. By not keeping his tanks concentrated at the allocated position, he had missed an opportunity. It is difficult to see why this was allowed to slip by, considering that Gatehouse was an experienced commander, who should have understood that the aim of Operation Crusader was to bring the German tanks to battle and to destroy them, and that Gabr Saleh was a critical position in this regard.

Most importantly, despite an order to stay in place and reconnoitre west, he had allowed his tank regiments and supporting artillery to spread out between Taieb el Essem and Sidi Azeiz to the north to deal with numerous enemy reports, none of them critically important. Arguably, if he had followed orders, he could have met Group Stephan with the whole of his brigade, fielding a superior tank force. As it was, $5^{\text {th }}$ RTR arrived at the battle too late to make an impact and, by the end of 19 November, $3^{\text {rd }}$ RTR, having only received the order to recall at 16:00, remained widely dispersed, far away from the main body of $4^{\text {th }}$ Armoured Brigade ( $4 \mathrm{AB}$ ). The regiment was running out of petrol and did not manage to assemble until after midnight. The expectation of the $7^{\text {th }}$ Armoured Division command is summarised in its war diary entry at 15:30, which states, "4 AB 
moves to intercept" rather than that a single regiment was ordered to hold off an attack by approximately 100 tanks. ${ }^{422}$

\section{Tank losses}

The basis for the criticism of the British performance by Agar-Hamilton and Turner is the perceived lopsided nature of tank losses in this battle. ${ }^{423}$ The criticism is based on the loss or damage reports by both sides, which reported eight German tanks lost to 23 British, and is combined with the accusation of overclaiming, with the British reporting 20 to 26 enemy tanks and nine troop carriers destroyed. ${ }^{424},{ }^{425}$ It must be noted that the loss reporting for the Germans and British tank forces did not allow direct comparisons.

It is important, in this regard, to take into account the detailed loss report of 21 Panzerdivision, which listed every tank lost by Panzerregiment 5 during the period 18 November to 15 December 1941 by turret number, with a detailed explanation for the loss. On 19 November, eight tanks were reported lost to enemy action and technical issues, turret numbers I11, I02, 121, 122, 125, 131, 221 and 531. ${ }^{426}$ It is noteworthy that all eight tanks reported were labelled as either destroyed outright (121 and 125) or requiring recovery either for battle damage (I11, I02, 122, 131, 221) or technical faults (531). ${ }^{427}$ This compares to 11 permanent losses suffered by $8^{\text {th }}$ Hussars and amounts to a fairly even exchange rate, given the initial strength ratios.

\begin{tabular}{|c|c|c|c|c|c|}
\hline $\begin{array}{c}\text { Date of } \\
\text { evening report }\end{array}$ & $\begin{array}{c}\text { Tanks } \\
\text { reported } \\
\text { operational }\end{array}$ & $\begin{array}{c}\text { Tanks reported } \\
\text { lost or detached }\end{array}$ & $\begin{array}{c}\text { Implied } \\
\text { operational } \\
\text { tanks }\end{array}$ & $\begin{array}{c}\text { Difference } \\
\text { (daily) }\end{array}$ & $\begin{array}{c}\text { Difference } \\
\text { (cumulative) }\end{array}$ \\
\hline 17 November & 120 & $\mathrm{n} / \mathrm{a}$ & 120 & 0 & 0 \\
\hline 18 November $^{1}$ & 120 & $3(\mathrm{~d})$ & 117 & 0 & 0 \\
\hline 19 November $^{2,3}$ & 83 & $8(1)$ & 109 & -34 & -26 \\
\hline 20 November $^{2}$ & 82 & $4(1)$ & 105 & +3 & -23 \\
\hline 21 November & 67 & $4(1)$ & 101 & -11 & -34 \\
\hline 22 November & 57 & $10(1)$ & 91 & 0 & -34 \\
\hline 23 November & 45 & $17(1)$ & 74 & +5 & -29 \\
\hline
\end{tabular}

Table 6: Tank reporting discrepancies Panzerregiment 5, 17 to 23 November $1941 .{ }^{428}$

${ }^{1}$ One company detached to support Group Wechmar

${ }^{2}$ One company detached to engage Allied armoured cars

${ }^{3}$ Both detached companies returned to regiment

It is, however, likely that $8^{\text {th }}$ Hussars did considerably better than an even exchange, since the reported German losses raise serious questions. The report of eight tanks lost does not explain the steep drop in available tanks of Panzerregiment 5 between the evenings of 18 and 19 November as set out below. While some attempts have been made to explain the discrepancy, e.g. by presuming lower availability due to the impact 
of Operation Sommernachtstraum in September, these ignore the fact that the reporting was not aligned over several days. ${ }^{429}$

A more likely explanation is based on a consideration of the loss classification. The labels assigned to the lost tanks indicate that damaged tanks that did not require recovery were not listed as losses in the divisional records, presumably because they were expected to be repaired by their crews or regimental workshops overnight. While it is not clear what happened to the missing tanks, the number of tanks missing from the accounting aligns well with the claims made by $8^{\text {th }}$ Hussars and $4^{\text {th }}$ Armoured Brigade, especially if some of the nine troop carriers claimed by $4^{\text {th }}$ Armoured Brigade were also tanks.

\section{Tactical and operational outcomes}

The established view of the battle is that the German tanks of Group Stephan prevailed over 4th Armoured Brigade on 19 November with minimal losses. In the established view is furthermore accepted that the Germans owned the battlefield at the end of the engagement and managed to recover their lost tanks. ${ }^{430}$ Finally, part of this view is that the British side severely overclaimed German tank losses, claiming at least 20 destroyed tanks, and that the British tank regiments suffered from tactical weaknesses compared to the Germans, and these weaknesses are seen as the reason for the lopsided tank losses being inflicted on the British tank forces. ${ }^{431}$

Based on a review and analysis of the primary evidence, a different picture emerges, namely that while the battle could best be described as a tactical draw, operationally it was a clear British victory. The established views on the battle are based on a misinterpretation or lack of knowledge of the primary evidence on both sides, both regarding the development of the battle and the operational context within which it was fought.

The available evidence from primary sources furthermore suggests that misinterpretation of the battle has also led to an almost complete failure to appreciate the impact of the successful defence battle at operational level. It is normally not considered that Group Stephan did not have one, but two objectives:

- $\quad$ to destroy the estimated 200 tanks of $4^{\text {th }}$ Armoured Brigade; and

- $\quad$ to advance east to the Libyan-Egyptian frontier, into the rear of 7 Indian Brigade at Libyan Omar, to relieve pressure on the Axis frontier garrisons. ${ }^{432}$

First and foremost, at tactical level, the established view takes German loss reports at face value, while comparing them directly to the loss reports of 8th Hussars, even though this is not possible due to different categorisations. The established view also usually assumes that the German tanks leaguered on the battlefield for the night, thereby controlling recovery efforts of damaged tanks. Considering the available evidence, from both the German and the Allied side, it is highly likely that the German tank losses on 19 November were understated, challenging this traditional view of the battle. Thus, the charge that the British were overly optimistic when counting German tanks destroyed 
has to be examined closely in the light of the available tank loss and readiness data of Panzerregiment 5, in particular the discrepancy of 26 tanks missing from the roster on the evening of 19 November.

Furthermore, it is clear from the German message log that Group Stephan leaguered off the battlefield, and the disabled tanks ended up in no-man's land, with both sides engaging in recovery efforts. Given Group Stephan's failure to achieve its first mission, the conclusion that presents itself is that, rather than being beaten with heavy losses, the performance of $8^{\text {th }}$ Hussars meant that they managed to hold the line they were assigned against a superior German force while inflicting substantial damage on the advancing force, compelling it to abandon its mission.

At the operational level, Group Stephan had the mission to remove the threat to Libyan Omar and Sidi Omar, the two locations which constituted the western anchor of the fortification line running from Halfaya Pass to Libyan Omar. The plan seems to have been to catch any Allied forces in the area by using the tanks of Group Stephan to push the Allied forces against the fortifications of the garrison of Libyan Omar and Sidi Omar. ${ }^{433}$ On 19 November, $7^{\text {th }}$ Indian Brigade was arranged in a considerable line east of the border wire, running from west of Bir Sherferzen to Bir Bu Deheua, north-west of Libyan Omar. ${ }^{434}$ Given the nature and strength of Group Stephan, it would have been in a good position to inflict at least serious damage on $7^{\text {th }}$ Indian Brigade.

The successful defence of the track at Gabr Saleh by $8^{\text {th }}$ Hussars therefore prevented Group Stephan from achieving both the operational objectives given to it. Rather than destroying the whole of $4^{\text {th }}$ Armoured Brigade, Group Stephan managed to destroy just one tenth of the estimated enemy tanks and rather than being able to relieve the pressure on the frontier garrisons by attacking $7^{\text {th }}$ Indian Brigade, Group Stephan failed to advance east at all after being driven back at Gabr Saleh.

Nevertheless, while tactically successful, the Allied forces missed an operational opportunity. The opportunity that presented itself on 19 November was to deal the German tank force a severe blow early in Operation Crusader by defeating it in detail, after it had been split. Not realised at the time, and not considered in the literature, are two important facts relating to the battle:

- $\quad$ Rommel did split his armoured force, rather than concentrating it; and

- $\quad$ Rommel attacked in force at Gabr Saleh, something that Lieutenant-General Norrie did not believe he would do, and which he claimed in his report after the operation Rommel did not do.

Had $4^{\text {th }}$ Armoured Brigade been in a position to concentrate in time to meet Group Stephan, then it is at least possible that substantial damage could have been inflicted on Panzerregiment 5 at an early stage of Operation Crusader. That this did not happen was due to Brigadier Gatehouse failing to concentrate his brigade on 19 November. The dispersal of five of his nine tank squadrons and half of his artillery meant that he was not in a position to engage Group Stephan forcefully, since he was not able to achieve superiority at the point of contact in the short time between the battle commencing and 
dusk falling. Thus, command failures present in $4^{\text {th }}$ Armoured Brigade prevented the destruction of the attacking German tank force, which would have been achievable for the Allied side, had it been handled better. This was an early indication of a weakness noted by General Auchinleck in a message to Field Marshal Alanbrooke on 7 January 1942, following the disastrous battles by $22^{\text {nd }}$ Armoured Brigade at the Uadi el Faregh south of Agedabia. ${ }^{435}$

\section{Conclusion}

This article has revealed the complexities surrounding Operation Crusader. This was not a simple battle. The outcomes of tactical engagements were not clear at the time and even today present a challenge for scholars due to the loss of records in a battle where headquarters were often overrun. Weaknesses in command and assessment of tactical and operational opportunities were often obscured in the write-up, making the inquiry into the events more difficult.

The tank forces of the $8^{\text {th }}$ Army consisted of a wide range of regiments and experiences, such as the territorial army tank soldiers in the three infantry tank regiments of $1^{\text {st }}$ Army Tank Brigade and regular tank men in $4^{\text {th }}, 7^{\text {th }}$ Armoured and $32^{\text {nd }}$ Army Tank Brigades. Even the two cavalry regiments in the $4^{\text {th }}$ and $7^{\text {th }}$ Armoured Brigades and the $7^{\text {th }}$ and $8^{\text {th }}$ Hussars, had extensive tank experience gained in the desert for over half a decade. The only green ex-cavalry troops were the three more recently converted armoured regiments in 22 Armoured Brigade, which had not seen fighting at all, but had trained extensively in England throughout 1941.

It is clear from the evidence presented in this article that the dismissive attitude taken towards the quality of British cavalry regiments that had been converted to armour, implied, for example, in Crisp's description of Brigadier Gatehouse cited above and indeed in Moorhouse's description of the battle as a 'reckless' charge, did not apply universally. The claim by Barnett, that "the officers and men of the British armoured brigades were as generally untouched by these warnings [on enemy tactics, contained in a training memorandum issued in September 1941] as road-hogs by road safety propaganda" cannot be confirmed based on the performance of $8^{\text {th }}$ Hussars on 19 November 1941. Instead, as in any army, the performance of units varied based on their experience and training, and it is not appropriate to attribute a universal qualification to an arm of service, and on the afternoon of 19 November 1941, $8^{\text {th }}$ Hussars delivered a performance that ensured that German operational intent was thwarted.

This article thus represents another step in a new and more comprehensive interpretation of the performance of British and Empire formations in the early phase of the desert war, addressing many of the myths and misconceptions that have coloured our perception for too long. ${ }^{436}$ 


\section{ENDNOTES}

${ }^{354}$ Author contact: 683942@soas.ac.uk; Andreas is an independent historian based in London, UK. He specialises in the desert war, 1941/42, focusing on Operation Crusader, and shares his research through his blog http://rommelsriposte.com and on Academia. edu at https://independent.academia.edu/AndreasBiermann. The author is indebted to the reviewers; in particular, this article has greatly benefited from the review and comments by Profs Alan Allport and Marcus Faulkner and Drs Philip W Blood and Ben Wheatley and the insights of the Scientia Militaria referees.

${ }^{355}$ While at the time of Operation Crusader the usual term would have been 'Empire', the more usual 'Allied' is used throughout this note as more accurate than the alternative 'Commonwealth', considering the composition of Eighth Army as well as the Allied naval and air forces at the time of Operation Crusader.

${ }^{356}$ General Cunningham, GOC Eighth Army from its creation, relieved of his duties on 26 November 1941.

${ }^{357}$ General Richie, GOC Eighth Army from 27 October 1941 to the end of the operation.

${ }^{358}$ C Auchinleck. "Operations in the Middle East from 1 November 1941 to 15 August 1942". Supplement to the London Gazette 38177. 15 January 1948. 312.

${ }^{359}$ Map II from “The Mediterranean and the Middle East”, Vol. II. Undated. $<$ https://www. ibiblio.org/hyperwar/UN/UK/UK-Med-II/maps/UK-Med-II-2.jpg $>$ Accessed on 15 February 2021.

${ }^{360}$ C Barnett. The desert generals. London: William Kimber, 1960, 106.

${ }^{361}$ R Lyman. Tobruk: The longest siege. Basingstoke: PanMacmillan, 2010.

${ }^{362}$ Sheet 14 Bardia. Eighth Army Mapping Services, 1942, Author's collection.

$36330^{\text {th }}$ Armoured Corps will be referred to as 30 Corps. While modern references to corps are in Roman numerals, this article uses Arabic numerals to facilitate distinction between Allied and Italian army corps. Under the field regulations in force in 1941-42, British corps were numbered with Arabic numerals.

364 'Marmarica' refers to the eastern part of Libya, named after the Roman Empire province of antiquity, with Tobruk as its administrative capital. It ranged from the border with Egypt to a north-south line approximately at the Gulf of Gazala, approximately $60 \mathrm{~km}$ west of Tobruk. Cyrenaica is the province west of this line to a north-south line approximately at the Ras Lanuf, approximately $200 \mathrm{~km}$ west of Agedabia, at the ancient border of Roman and Carthaginian lands in modern Libya, with Benghazi as its capital. West of this line to the border with Tunisia was the province of Tripolitania, with Tripoli as its capital. The border between the provinces at Ras Lanuf was marked by the Arco dei Fileni, a triumphal arch through which the Via Balbia coastal road passed. It was known as 'Marble Arch' to British soldiers. In British history, the term 'Cyrenaica' is often used to cover both Cyrenaica and Marmarica.

${ }^{365}$ UK National Archives (TNA), WO201/2693 - 8 Army report by the GOC, SeptemberDecember 1941, par. 7, p. 3.

${ }^{366}$ TNA, WO169/1175, appendices - while the grid references in this map differ slightly from those on Map 2, they are used, as this was the map utilised by the $7^{\text {th }}$ Armoured Division units during the battle, and it was therefore the basis for any location references in their war diaries.

${ }^{367}$ All references refer to the grid of Map 1.

368 TNA, WO201/2693.

${ }^{369}$ National Archives and Records Administration (NARA), T-315 R66415. Panzerdivision, KTB No. 2 and IWM Duxford EDS (EDS) AL966 Panzerregiment 5 battle report, entry 17 November. 
${ }^{370}$ M Montanari. Le Operazioni in Africa Settentrionale - Vol. II Tobruk. Rome: Ufficio Storico dello Stato Maggiore dell'Esercito, 1993.

${ }^{371}$ The table is based on a mix of information, including OOB and actual data.

${ }^{372}$ Excerpt of Map 35a from the US Army West Point Military Academy map collection, titled "North Africa 1940: Auchinleck's offensive 10 November 1941 - 31 December 1941". Undated. $<$ https://www.westpoint.edu/sites/default/files/inline-images/academics/ academic_departments/history/WWII\%20Europe/WWIIEurope35Combined.pdf> Accessed on 16 March 2021.

${ }^{373}$ R Hammond. Strangling the Axis: The fight for control of the Mediterranean during the Second World War. Cambridge Military Histories. Cambridge: Cambridge University Press, 2020.

374 The Italian High Command of the Armed Forces in North Africa.

${ }^{375}$ General Enno von Rintelen, 1891 to 1971, military attaché and from Italy's entry into the war German general at the Italian High Command, from 1936 to 1943.

${ }^{376}$ While not normally used in English-language histories, the term 'Marmarica' denotes the eastern half of what is commonly referred to as 'Cyrenaica', a separate province with Tobruk as its capital. The border to the east is Sollum, while to the west it is situated at modern Derna. See doi: 10.1093/acrefore/9780199381135.013.3974

${ }^{377}$ Africa Special Purpose Division - German: Division z.b.V. Afrika was a division-size formation assembled to provide the German infantry element of the assault, with 15. Panzerdivision providing the armoured element.

${ }^{378}$ Panzergruppe Afrika, formed in August 1941 to control the German Africa-Korps and the siege operations around Tobruk. It was under the command of Rommel, with General Gause as chief of staff.

${ }^{379}$ German special purpose division for the siege of and assault on Tobruk. Renamed $90^{\text {th }}$ Light during the battle.

${ }^{380}$ Montanari op. cit.

${ }^{381}$ Reconnaissance Group = Aufklärungsgruppe.

${ }^{382}$ Reconnaissance Battalion $=$ Aufklärungsabteilung (AA) 3 and AA33.

383 Anti-tank Battalion 39 = Panzerjägerabteilung 39. This was equipped with three companies of anti-tank guns, each with two platoons of obsolete $37-\mathrm{mm}$ and one platoon of more modern 50-mm PAK38 AT guns. Each platoon had three guns. EDS 355, Order of Battle $21^{\text {st }}$ Panzer Division.

${ }^{384}$ Bundesarchiv Militärchiv (BAMA), RH27/21/1.

${ }^{385}$ R Crisp. Brazen chariots. New York, NY: Bantam Books, 1978, 10.

386 TNA, WO169/952, sheet for 11 November 1941.

${ }^{387}$ Hoover Institution. Bonner-Fellers papers, Box 39, Folder 8, Message 279, 1 December 1941.

388 TNA, WO169/949, Artillery statement Middle East 4 November 1941, CRME/3613/RA, dated 5 November 1941.

${ }^{389}$ Friedrich Stephan, 21 February 1898 to 25 November 1941, as lieutenant participant in the second course at the German tank school in Kazan 1931/32. He had taken command of the regiment in July 1941, following the BATTLEAXE Operation. Also see HG Krampe. Militärgeschichtliche Blätter: Wünsdorf - Geburts - und Entwicklungsstätte der deutschen Panzertruppen. Berlin: Verlag Meißler, 2005; B Hartmann. Panzers in the sand. Barnsley: Pen and Sword Military, 2011. There are few descriptions of him, as he died only six days after this battle in an air attack. First-hand accounts contained in Hartmann indicate a disciplinarian, with a somewhat brusque manner. 
${ }^{390}$ TL Jentz. Panzertruppen Vol. 1. Atglen, PA: Schiffer Military History, 2004 notes that the majority of the Panzer III of the regiment were of the ' $G$ ' variety with $30-\mathrm{mm}$ frontal armour, with only four gun tanks being ' $\mathrm{H}$ ', which were up-armoured with an additional $30-\mathrm{mm}$ plate welded onto the front and which could not be penetrated by the 2-pdr gun over their frontal arc at normal combat ranges.

${ }^{391}$ TNA, WO169/1388, war diary 8 Kings Royal Irish Hussars, January-December 1941, entry 19 November 1941.

${ }^{392}$ TL Jentz \& HL Doyle. Panzer tracts No. 3-2: Panzerkampfwagen III Ausf. E, F, G und H: Development and production from 1938 to 1941. Boyds, MD: Panzer Tracts, 2007, 15; RP Hunnicutt. Stuart: A history of the American Light tank. Novato, CA: Presidio Press, 1992; Undated C Ankjersterne, “ $5 \mathrm{~cm} \mathrm{Kw} \mathrm{K”.} \mathrm{<https://panzerworld.com/5-cm-kw-k>}$ accessed on 24 March 2021. Jentz and Doyle note that up-armouring of Panzer III E, $\mathrm{F}$ and $\mathrm{G}$ variants with an additional face-hardened 30-mm armour slab commenced in the field, utilising factory-supplied kits, in December 1940. This addition would have rendered the Panzer IIIG considerably better able to resist the Stuart's gun at typical combat ranges. Nevertheless, photographic evidence shows that this additional armour had not been applied to Panzerregiment 5 tanks by April 1941, when they were in Africa. There is no photographic evidence available that would indicate that the situation had changed by November 1941. Given the supply challenges in North Africa, it is an open question whether the Panzer IIIG tanks of Panzerregiment 5 were up-armoured.

${ }^{393}$ Aufklärungsgruppe Wechmar, named after the commanding officer of Aufklärungsabteilung 3.

${ }^{394}$ Kampfgruppe Stephan, named after Lieutenant-Colonel Stephan, the commanding officer of Panzerregiment 5.

${ }^{395}$ NARA, T315 R157 Frame 121. Panzerdivision Ia KTB No. 2, entry 19 November 1941.

${ }^{396}$ Map prepared by Mike Bechtold, commissioned by the author: $<$ https://mikebechthold.com $/>$. ${ }^{397}$ Ibid.

${ }^{398}$ Crüwell had arrived in North Africa in September to take command of the Africa Corps after the creation of Panzergruppe Afrika as the superior German headquarters in North Africa. He was directly subordinated to General Rommel.

${ }^{399}$ BAMA, RH19/8/53, activity report Panzergruppe Afrika Ic, 18 November 1941 - 6 February 1942, message log Aufklärungsgruppe to 21. Panzerdivision, 18 November 1941.

${ }^{400} \mathrm{Ibid}$., daily summary, 18 November 1941.

${ }^{401}$ TNA, WO169/4503, $3^{\text {rd }}$ RTR war diary, 1942, unordered messages and map files.

${ }^{402}$ It is possible that these were the 'sunshield' camouflage devices used to conceal British tanks by making them appear as trucks.

${ }^{403}$ BAMA, RH19/8/53 op. cit.

${ }^{404}$ NARA, T315 R157 Frame 121 op. cit.

${ }^{405}$ NARA, T315 R664 KTB No. 2, entry 19 November 1941.

${ }^{406}$ TNA, WO169/1281, war diary $4^{\text {th }}$ Armoured Brigade, January-December 1941, entry 19 November 1941.

${ }^{407}$ Agar Hamilton and Turner claim the message may not have been received by $4^{\text {th }}$ Armoured Brigade, but this is clearly not correct.

${ }^{408}$ TNA, WO169/1175, G branch $7^{\text {th }}$ Armoured Division, December 1941 and Appendices, message log, $7^{\text {th }}$ Armoured Brigade, message, 19 November 1941, 1530 hours; TNA, WO169/1281, entry 19 November; TNA, WO169/1388, war diary, 8 Kings Royal Irish Hussars, January-December 1941, entry 19 November 1941.

${ }^{409}$ TNA, WO169/1281, entry 19 November 1941.

${ }^{410}$ TNA, WO169/1175, $4^{\text {th }}$ Armoured Brigade, message, 19 November 1941, 1602 hours.

${ }^{411}$ BAMA, RH27/21/2a, evening report by Panzerregiment 5, 0240 hours, 20 November 1941, Frame 000214. 
412 TNA, WO169/1388, war diary, $8^{\text {th }}$ Hussars, entry 20 November 1941.

${ }^{413}$ BAMA RH27/21/2b, frames 000861-000863.

${ }^{414}$ TNA, WO169/1175, messages from $4^{\text {th }}$ Armoured Brigade 1624, 1700, 1728 hours, 19

November.

415 TNA, WO169/1414, entry 19 November.

${ }^{416}$ It is also notable that the unit history of $5^{\text {th }}$ RTR does not mention the fight on 19 November at all. See M Urban. The Tank War. London: Hachette Digital, 2013, Kindle edition; JAI Agar Hamilton \& LCF Turner. The Sidi Rezegh battles. Cape Town: Oxford University Press, 1957, 144.

${ }^{417}$ See, for example, Agar Hamilton \& Turner op. cit., p. 144; DB Katz. South Africans against Rommel. Guilford, CT: Stackpole Books, 2018, Kindle edition, loc. 2345; TNA, WO169/1427, $2^{\text {nd }}$ RHA, January-December 1941, entry 19 November 1941; BAMA $\mathrm{RH} / 21 / 2 \mathrm{~b}$ and TNA, WO169/1175 7, message from $4^{\text {th }}$ Armoured Brigade, 1858 hours, 19 November. The reason for this claim cannot be ascertained at this stage, but it is clear that it is not correct.

${ }^{418}$ BAMA RH/21/2b; TNA, WO169/1427, entry 19 November 1941; probably tank rounds rather than artillery.

${ }^{419}$ Either prime movers or tanks, given that no infantry was present on the German side; nevertheless, this appears unlikely, given that no guns seem to have been lost by Group Stephan; TNA, WO169/1281, war diary, $4^{\text {th }}$ Armoured Brigade, entry 19 November; TNA, WO169/1175, $4^{\text {th }}$ Armoured Brigade, message, 1945 hours, 19 November 1941; TNA, WO169/1414, entry 19 November 1941.

${ }^{420}$ British vehicle casualties are classed as ' $\mathrm{X}$, ' $\mathrm{Y}$ ' and ' $\mathrm{Z}$ '. $\mathrm{X}$ casualties are minor damage, repairable by crew overnight. $Y$ casualties require support from specialist fitters or repair by the LAD or at the Brigade workshop, while $\mathrm{Z}$ casualties are either completely destroyed or repairable only at a major workshop.

${ }^{421}$ RH27/21/2b, Meldungen, November 1941; Imperial War Museum, Enemy Document Section Duxford 355 AL500/1/10 Pz. Armee Afrika Schlachtbericht, Anlage 9 Tagesmeldung, 19 November 1941.

${ }^{422}$ TNA, WO169/1411, war diary, $3^{\text {rd }}$ RTR, January-December 1941, entry 19 November; TNA, WO169/1174, war diary, $7^{\text {th }}$ Armoured Division, January-December 1941, entry 19 November, 1530 hours.

${ }^{423}$ See discussion in Agar Hamilton \& Turner op. cit., p. 142ff.

${ }^{424} 8^{\text {th }}$ Hussars only lost 11 tanks permanently, with the remainder repaired within 48 hours after the battle (Agar Hamilton \& Turner op. cit.). This is in line with the tank numbers reported in the war diary, which states that at least six tanks were lost on 20 and 21 November, bringing the total lost to 26, and that approximately 25 tanks were remaining when going into leaguer on 21 November. On 26 November, Major Sandbach from $8^{\text {th }}$ Hussars brought in $36 \mathrm{M} 3$ tanks from TDS, indicating that at least 12 tanks had been repaired in the meantime, assuming all 22 reserve tanks had been issued. TNA, WO169/1281, war diary, $4^{\text {th }}$ Armoured Brigade, 26 November 1941.

${ }^{425}$ German tank losses are given as two destroyed and six damaged, one of which for technical reasons, while $8^{\text {th }}$ Hussars reported $20 \mathrm{M} 3$ lost, and $5^{\text {th }}$ RTR reported one tank lost and two mechanical casualties; see WE Murphy. The relief of Tobruk. Wellington: Historical Publications Branch, 1961, 85.

${ }^{426}$ BAMA RH27/21/2a; I11 was a Panzer II and I02 a Panzer III in the command section of I. Abteilung, while the remainder were Panzer III in 1., 2. and 5. Kompanie of the regiment.

${ }^{427}$ Bergebedürftig.

${ }^{428}$ BAMA RH27/21/2a 000214-000220. 
${ }^{429}$ Imperial War Museum, Enemy Document Section, AL923 18572/4 Anlagen zum KTB No. 2, 30 January - 31 March 1942, p. 330. Report by Ic regarding divisional history, 18 February 1942; Murphy op. cit., p. 85, picks up this discrepancy in a footnote. $\mathrm{He}$ tries to explain it by suggesting a long-term effect of Operation Sommernachtstraum on 14-15 September 1941, or an attempt to disguise the poor state of readiness of Panzerregiment 5 towards Berlin. Neither of these two explanations can be considered convincing.

${ }^{430}$ See, for example, R Stolfi. German battle style in ultra mobile, high intensity war: North African Desert 1941-42. Monterey, CA: Naval Postgraduate School, 1991, 25 and Hartmann op. cit.

${ }^{431}$ See, for example, B Pitt. Auchinleck's command: The crucible of war Book 2. Sharpe Books, 2019, Kindle edition, Stolf op. cit. and Montanari op. cit., while other examples of this view can be found in the South African semi-official history, the New Zealand official history and also the despatch by General Auchinleck himself. See Agar Hamilton \& Turner op. cit.; Murphy op. cit.; Auchinleck op. cit.

${ }^{432}$ Location 49503600 on Map 2.

${ }^{433}$ Location 495360 on Map 2.

${ }^{434}$ Locations 494345 and 490364, respectively, on Map 2.

${ }^{435}$ E McGilvray. Field Marshal Claude Auchinleck. Yorkshire: Pen \& Sword Military, 2020, Apple iBook edition, 332.

${ }^{436}$ Barnett op. cit., p. 104. - while he does not identify the Training Memorandum, it was most likely WO201/2965 Middle East Training Memorandum No. 1: September 1941 (general; the arms; lessons from operations; enemy methods; enemy stores, arms and equipment). 